\title{
Szabó Vivien
}

\section{A légiközlekedésben használt biztonsági berendezések jellemzése repülőtéri terrorcselekményekkel kapcsolatban}

\author{
Vivien Szabó \\ The Characteristics of Airport Security Devices in Connection with \\ Terrorist Attacks
}

\begin{abstract}
Összefoglaló
A terrorszervezetek olyan helyeket és épületeket választanak elsődleges célpontnak, amelyeket nagy tömegek használnak,-mint például tömegközlekedési csomópontok. Cikkemben kiemelten foglalkozom a repülötereken elkövetett terrorcselekményekkel. A terroristák kis mennyiségü robbanóanyaggal képesek hatalmas robbantásokat okozni, ezzel kárt téve emberi életekben és építményekben. A folyamatos repülötéri biztonsági rendszerek fejlesztésével a terrorista csoportoknak is szükségük van új technikák alkalmazására. A terrorcselekmények sikertelen megelözése is bizonyítja, hogy rendszeres müszaki, emberi és technológiai fejlödésre lenne szükség. A modern terrorizmus történetében a fö célpontok a repülögépek a kifutópályán és levegöben, érkezési és indulási csarnokok, illetve forgalomirányítás és radar rendszerek. Úgy tünik a három nyilvános hely közül, az bizonyul a "leggyengébbnek”, ahol az utasokat és a poggyászokat ellenörzik. A légi közlekedés védelme érdekében ellenörzik az utasokat, a kézi poggyászaikat, a feladott poggyászaikat és a rakodótérbe bekerült szállítmányokat. A biztonsági ellenörzés fontos, mert ez az egyetlen módja, hogy megakadályozzuk a tiltott anyagok csempészetét és a robbanóanyagok feljuttatását a repülögép fedélzetére. Hasonló technológiát alkalmaznak a postahivataloknál is a csomagok ellenörzésére. A robbanásveszélyes anyagok kimutatására a múltban számos módszert kidolgoztak, így képesek az egészen kis mennyiségü anyagot is kimutatni. Ebben a cikkben bemutatom a biztonsági berendezéseket, alkalmazásait, típusait és müködési elveit.

Kulcsszavak: érzékelők, repülőtéri biztonsági rendszer, mechatronika, repülőtéri irányítás, kockázat, válság, kiszolgáltatottság
\end{abstract}

Abstract

Terror organizations threat those huge places and buildings which are used by a big mass of people. Public transportation hubs such as airports are most preferred places of terrorist attacks. If we prepare a small explosive device, we can cause a huge harm in the aircraft killing a lot of people. Security regulations have been improved to create new methods to prevent terrorist attacks. 
The main targets are at the airport the airplanes on the runway and already in the air, the arrival and departure halls, and the air traffic control and radar systems. To protect human life and airplanes in the airport security they check the passengers, their handluggage, their registered baggage and the cargo. I would like to show you how we can avoid the terrorist attacks and this present article gives an overview of the application of such equipment, their types and the working principles of the devices of airport security systems.

Keywords: sensors, airport security system, mechatronics, airport management, risk, crisis, vulnerability

\section{BEVEZETÉS}

A terrorszerveztek legfőképpen a tömegközlekedést fenyegetik. Az egyik legveszélyesebb helyek közé sorolhatjuk a repülőtereket, ahol egy kis mennyiségú robbanóanyag is hatalmas balesetet tud okozni. A terroristák folyamatosan fejlesztik módszereiket, hogy terveiket megvalósítsák és nyilvános területeket sikeresen támadjanak meg. Még ha nem is sikeres az összes kísérlet, egyértelmúnek tűnik, hogy a biztonsági rendszerek folyamatos javítása elengedhetetlen. Jelentős figyelmet kell fordítani, a nyilvános területekre, mint például indulási és érkezési csarnokok, repülőgépekre a földön és levegőben, valamint a légiforgalmi irányításra és a radarberendezésekre. A reptér leggyengébb pontja az indulási és az érkezési terminál. Emberek hatalmas tömege várakozik ott, akiket még nem ellenőriztek le biztonságilag. Minél nagyobb az áldozatok száma, annál nagyobb a politikai hatása a támadásnak és annál jelentőségteljesebb üzenetet hordoz magában a támadás. Az ilyen tömegpusztító próbálkozások ellen az egyetlen mód a védelemre, ha fejlesztjük az ellenőrzési módszereket. A 2001. szeptember 11-ei terrortámadás megmutatta mennyire sebezhető a légi közlekedés. Az 1970-es évek középpontjában elsősorban a gépeltérítés és a repülőgépen elhelyezett robbanóanyagok voltak. A terrorcselekmények rámutatnak arra, hogyan válhatnak a repülőgépek és a repülőterek a terroristák preferált célpontjaivá, valamint arra is rávilágítottak, hogy az általuk használt robbanóeszközök a kiskereskedelemben kapható termékekből előállítható. [4] [6]

Repülőterek biztonsági területei Biztonsági szempontból a repülőtereket több zónába sorolják. A földi oldalon a leggyengébb a biztonság, a légi oldalon erősebb, a szigorított biztonsági területeken és a privát területeken pedig a legjobb a védelem.

\section{1. ábra: A repülőterek felosztása biztonsági szempontból (Forrás: [1] )}

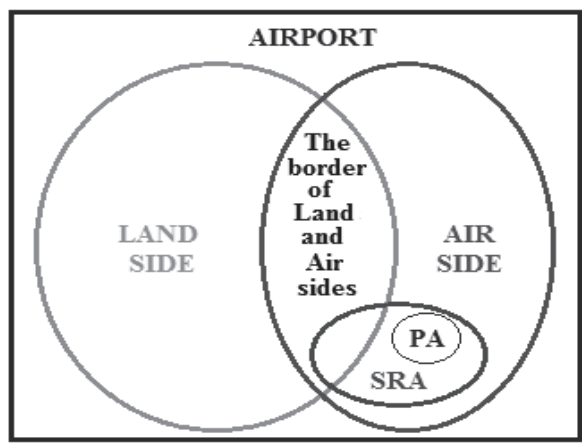

Sem a humán, sem a fizikai tényezők nem nyújtanak 100\%-os védelmet a terrortámadások ellen. A repülőterek földi oldala nyilvános, míg a légi oldal el van zárva a nyilvánosság elől, és csak engedéllyel (dolgozói kártya, beszállókártya, stb.) lehet a területre menni illetve akkor, ha az illető átesik egy 
biztonsági ellenőrzésen. A földi és a légi oldal között található az utasbiztonsági ellenőrzés.

A légi és földi oldalt falakkal, kapukkal, kerítéssel választják el egymástól. A privát terület az egyik speciális külön rész a szigorított védelmi területen belül, ahol csak a személyzet közlekedhet különböző speciális engedélyekkel (pl.: légiforgalmi irányító torony). Szintén a szigorított biztonsági területhez tartozik, a feladott poggyászvizsgáló rendszer. A repülőtéri csomagellenőrző rendszerek és a különböző érzékelők, mechatronikai rendszerként működnek, amelyek támogatják a védelmet a repülőtéri terrortámadások ellen. [1] [3]

\section{MÉRŐRENDSZEREK FELÉPÍTÉSE, MŰKÖDÉSÜK} ALAPJA

$A z$ utasbiztonsági ellenőrzésen különböző érzékelőkkel ellátott mechatronikai berendezéseket használnak. A szenzorok nem múködnek saját maguk által. Ezek általában összetettebb jelfeldolgozó rendszerek, memória, adatrögzítők. Valamennyi rendszer lehetne például mérési rendszer, adatgyújtő rendszer, vagy folyamatirányító rendszer. A szenzorok helye az eszközökben lehet kívül és belül, de mindig részei az adatgyúitő rendszernek. A következő ábra mutatja az adatgyújtő eszközt és a vezérlő eszközt.

2. ábra: Szenzorok elhelyezkedése egy adatgyűjtő rendszerben (Forrás: saját szerkesztés)

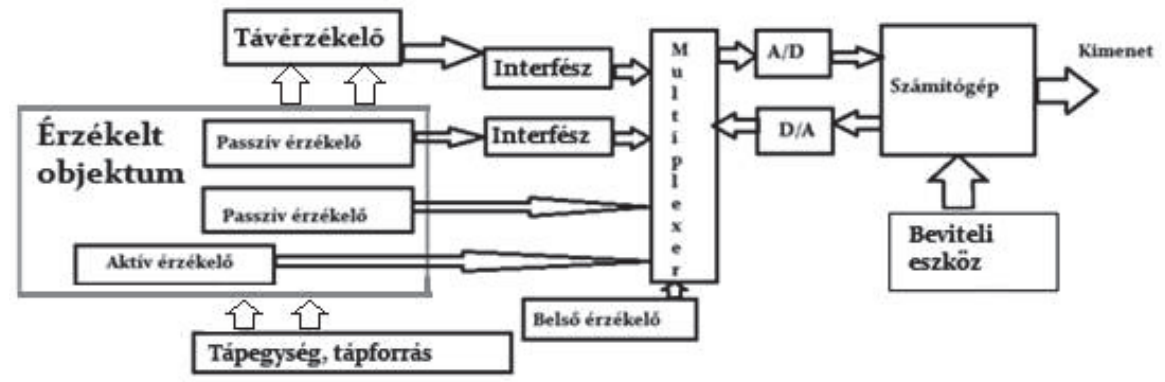

Az érzékelt objektum lehet, például egy pilóta nélküli repülőgép, egy környezet, egy személy, bármilyen robbanószerkezet (pl.: rögtönzött robbanószerek, IED-k), egy terület, valamilyen folyadék, vagy akár drogok. Az érzékelt objektum bármelyik fajtáját képesek vagyunk egy meghatározott rendszer segítségével megmérni. Az adatokat a szenzorok gyújtik össze. A távérzékelő szenzorok a tárgyakat fizikai kontaktus nélkül érzékelik (pl.: sugárzás kibocsájtó detektorok, IR kamerák). A belső szenzorok eltérő célt szolgálnak. Folyamatosan figyelik az adatgyűjtő/ellenőrző rendszer belső kondícióit. A szenzorok nem feltétlenül kapcsolódnak közvetlenül villamos áramkörökhöz.
Ezek az interfész eszközök használatát igénylik. Egy eszköz tartalmazhat egy vagy akár több ezer szenzort is. A szenzorok kimeneti villamos jele egy multiplexer bemenetére kapcsolva kapuzó áramkörként fog múködni. A szenzorok egyesével kapcsolódnak egy $A / D$ átalakítóhoz, ha a szenzorok kimenete analóg vagy közvetlenül a számítógépre továbbítható digitális jeleket bocsájt ki. A számítógép vezérli a multiplexert és az $A / D$ átalakítót, hogy biztosítsa a megfelelő időzítést. Ez a rendszer tartalmaz még néhány perifériás eszközt (mint például egy adatrögzítő, egy kijelző, egy riasztó, stb.) és számos egyéb összetevőt. Ezek lehetnek szűrők, erősítők, és így tovább. [4] 


\section{ÉRZÉKELŐK FELÉPÍTÉSE}

$\mathrm{Az}$ érzékelők információkat gyűjtenek a mérendő adatokról. Az érzékelők felelősek, hogy a bementi fizikai jellemzőkből (mennyiség, állapot) alakítsanak egy mérhető elektromos jelet (feszültség, áram), ami kompatibilis az elektronikus áramkörökkel. A kimeneti jelek lehetnek amplitúdók, frekvenciák, fázisok és digitális kódok. Ezeket a jeleket lehet továbbítani, szúrni, feldolgozni. A szenzorokat úgy is ismerik, mint energia-átalakítók, kapcsolatot hoznak létre a környezet és a rendszer között azzal, hogy a külső hatásokat villamos jelekké alakítják, amik lehetnek analóg vagy digitális jelek.

\section{3. ábra: Közvetett mérésű egyszerű szenzor (Forrás: [2])}

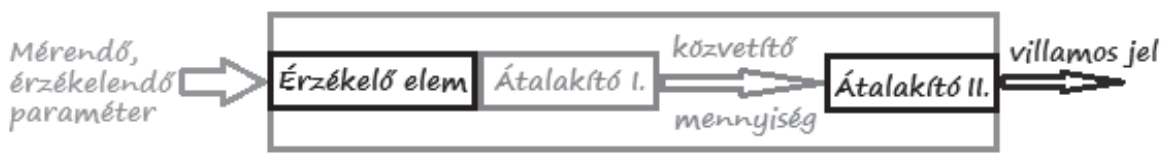

A következőképpen lehet értelmezni:

$$
S=f_{(s)}, \text { ahol }
$$

"S" a kimeneti jel, az $\mathrm{s}$ az inger, és az,,f(s)" reprezentálja a funkcionális kapcsolatot.

$\mathrm{S}=\mathrm{C}+\mathrm{ms}$, ahol

"C" kimeneti értéke nulla, és az „,m” értéke állandóan konstans (érzékenység).

A fent említett kapcsolatnak lineárisnak vagy nem lineárisnak, egyetlen értékúnek vagy nem egyetlen értékűnek, egydimenziósnak vagy többdimenziósnak (egy bemenet, egy kimenet, több bemenet, több kimenet) kell lennie. Ezt nehéz a matematika nyelvén leírni, ezért gyakran kalibrációs adatok segítségével tudjuk megadni, amit legtöbb esetben a készülék méréstartománya határoz meg. A legtöbb szenzor lineáris tartományban múködik, de egy szúk tartományban nem lineáris karakterisztikát mutat. A nemlináris szenzor válaszát a következőképpen határozzuk meg:

$$
S \approx A\left(1+k s+\frac{k^{2}}{2 !} s^{2}+\frac{k^{3}}{3 !} s^{3}+\cdots\right), \text { ahol }
$$

„A" egy paraméter, és „, $\mathrm{k}$ ” teljesítménytényező.
Három fajta szenzort használnak a jelfeldolgozó rendszerek: egyszerű érzékelők, beépített érzékelők és intelligens érzékelők. Ha megvizsgáljuk a mérendő ingert, amit lehetetlen átalakítani villamos jellé, szükségünk van egy úgynevezett „közvetett mérésre”. A közbenső mennyiséget elsősorban át kell alakítani egy elsődleges villamos mennyiséggé, amely során különböző fizikai hatások mennek végbe. Például egy kémiai szenzor első része átalakíthatja a kémiai energiát hővé, míg a másik része a hőt átalakíthatja villamos jellé. Ha nincs szükségünk az elsőszámú átalakításra, akkor tehetünk közvetlen mérést is. Közvetlen méréseket alkalmazunk, amikor a fizikai hatásokat alakítjuk át közvetlenül energiává, és létrehozzuk vagy módosítjuk az villamos jeleket. Egy integrált szenzorban az érzékelő modul feldolgozza és felerősíti az elsődleges villamos jeleket, és kompenzálja a jeleltolódást.

Az integrált érzékelők kiszúrik a zavarjeleket, linearizálják a hasznosakat, és a mérési tartománynak megfelelően normalizálják azokat. A digitális jel feldolgozása érdekében át kell alakítanunk az analóg kimeneti jelet digitális jellé, amit az A/D átalakító hajt végre. 
4. ábra: Egyszerű szenzor: Közvetlen mérés (Forrás: [18])

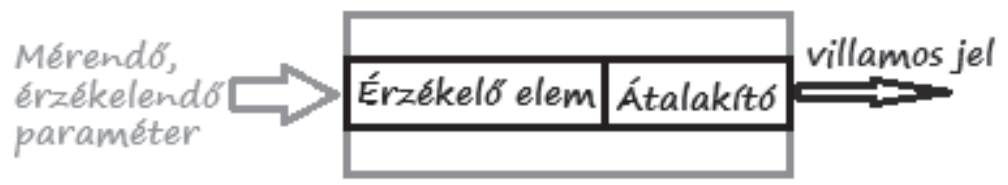

5. ábra: Integrált szenzor (Forrás: [18])

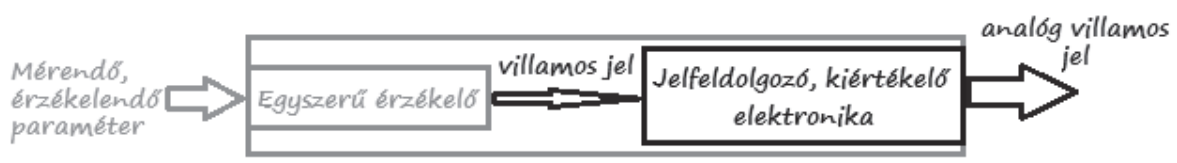

6. ábra: Intelligens (okos) érzékelő (Forrás: [18])

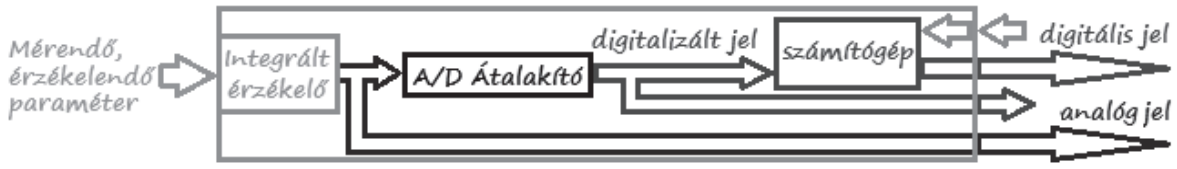

A mikroelektronikai alkatrészek feltalálása óta, a digitális kiértékelő egységeket

Feladott és kézi poggyász átvilágító (mikrokontroller) beépítették az érzékelőkbe. $A z$ érzékelők osztályozása függ az érzékelők feladatának céljaitól. Különböző osztályozási módszereket használnak.

A külső energiaforrás múködéséhez szükséges kimeneti jelek közötti kölcsönös kapcsolat alapján, illetve a kiválasztott referencia jel vagy a mérendő jel típusa szerint csoportosíthatjuk azokat. [2] [4] [5] [18] [19] [20]

\section{UTASBIZTONSÁGI ELLENŐRZÉSEN HASZNÁLT BERENDEZÉSEK, ESZKÖZÖK}

A repülőtéri utasbiztonsági ellenőrzésnél a következő eszközökkel találkoznak az utasok: röntgengép (kézipoggyászra), fémdetektoros kapuk, folyadékvizsgáló gép, robbanóanyag és drogdetektáló eszköz, és egyéb eszközök, mint például a kézi fémérzékelő múszer. [3]

Feladott és

A kettős energiaforrású röntgenberendezéseket gyakran használják a repülőterek biztonsági ellenőrzésénél. Ezek az eszközök 140-160 kV amplitúdójú jeleket bocsátanak ki különböző hullámhosszon. Miután a jelek áthaladnak a tárgyakon, a szenzorok érzékelik őket. A különböző anyagok különböző módon viselkednek. Vannak, amelyek elnyelik, és vannak amelyek, visszaverik a gépnek a különböző jeleit. Ebben az esetben a monitoron világosan feltúnik, milyen anyagokat és tárgyakat tartalmaz a poggyász. Ezek a különböző tárgyak különböző színnel jelennek meg a monitoron, attól függően, hogyan nyelik el az energiát. A színek különbséget mutatnak a szerves, szervetlen és fémes anyagok között. A repülőgépek, utasok mellett hatalmas mennyiségben árukat is szállítanak. A rakományt szintén ellenőrizni kell berakodás 
előtt, amire legtöbb repülőtér 2 különböző berendezést használ: a mobil röntgenberendezéseket és a rögzített helyszíni berendezéseket. [11][12][14] [16] [17]

\section{7. ábra: Tárgyak a monitoron (Forrás: [8])}

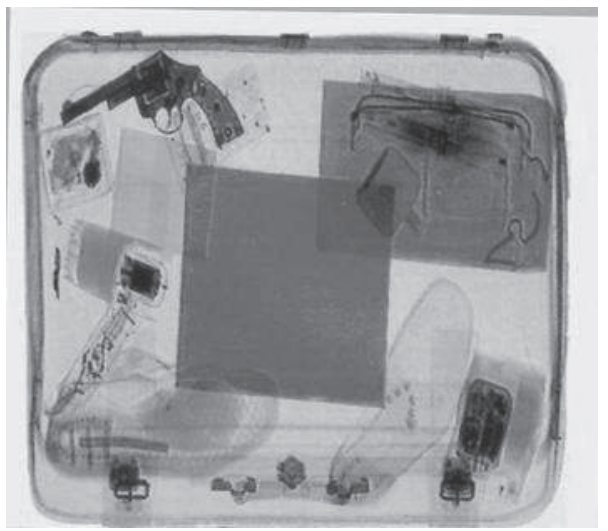

Fémdetektoros kapuk

Amikor az utasok átesnek az utasbiztonsági ellenőrzésen, nem csak a kézi poggyász ellenőrző berendezésekkel találkoznak, hanem a fémdetektoros kapukkal is. A múködési elve az összes fémdetektoros kapunak az impulzus indukción alapul, amely létrehoz egy mágneses mezőt. Az impulzus indukciós rendszer magában foglal egy adót és egy magas érzékenységú tekercset, amelyen rövid ideig áram folyik. Minden impulzus létrehoz egy mágneses mezőt. Amikor egy fémes tárgyat érzékel a fémdetektor, az impulzus létrehoz egy ellentétes mágneses mezőt az érzékelt objektumban. Amikor a mágneses mező összeomlik, létrehoz egy visszavert impulzust, és az érzékelt tárgy mágneses mezője eltűnteti az impulzust.

Robbanóanyag és kábítószer érzékelő berendezések

Számos repülőtéren használják, az úgynevezett „kémiai szimatolást”. A detektor textil részét végig húzzák a vizsgálni kívánt területen, mint például bőr, textil, múanyag vagy fém. A célja az ellenőrzésnek, hogy a gép detektálja azokat a kémiai anyagokat, amelyeket a vizsgált felületen talál, és ellenőrizze, hogy azok lehetnek-e összetevői drogoknak és robbanóanyagoknak. Ha a gép talál ilyen kémiai részecskéket, figyelmezteti az operátorokat. Ezeket az eszközöket használják elhagyott csomagok ellenőrzésére is. [9][10][15]

Folyadék-vizsgálógép

Egyre inkább elterjedt azon röntgengépek használata, amelyek mechanikai és elektronikai alkatrészeket foglalnak magukba. A folyadékvizsgáló gép az ellenőrzést a következő 3 lépésben hajtja végre: (1) érzékeli a tárgy helyzetét, (2) feldolgozza a digitális jeleket, (3) vizuálisan megjeleníti az eredményeket a számítógép monitorján. A mágneses rezonancia elvén a folyadék szkenner elemzi a különböző folyadékok molekuláris szerkezetét. A gépek képesek a folyadékokat analizálni akár 3 liter mennyiségig, függetlenül attól, hogy a palack üvegből vagy műanyagból készült-e. Amikor a sugarak keresztül hatolnak a folyadékon, megváltozik a jelek hullámhossza az adó és a vevő között. Ennek a segítségével tudjuk bizonyítani, hogy a folyadék milyen anyagokat tartalmaz. [1] [7]

\section{A REPÜLÉSBIZTONSÁG ÉS A "HUMÁN FAKTOR"}

A jól múködő utasbiztonsági berendezések mellett nagyon fontos, hogy jól képzett szakmai csapat alkalmazza azokat. Az operátorok képzése alapvetően egy előre meghatározott feladat megoldására épül. Különösen fontos, hogy jól megszervezzék és leoktassák az új anyagokat, ha új biztonsági rendszer vagy technológia van bevezetve a repülőtereken. Meg kell szerveznünk és végre kell hajtanunk azokat a képzési modulokat, amelyek segítenek 
fejleszteni az erre szakosodott dolgozók képességét. Megtanítani a biztonsági személyzetet, hogyan használják az eszközöket, közel nem elegendő, hiszen a tudás átadása nagyban függ az előadótól. A vezetőknek fontos, hogy egy belső motivációt, munkavállalói lojalitást kialakítsanak a dolgozókban és, hogy kialakuljon a csapatszellem. Fontos, hogy a légi közlekedésben legyen egy olyan humánerőforrást fejlesztő stratégia, amelynek középpontjában egy kockázatos, nem biztonságos, sőt veszélyes környezet foglal szerepet. Nincs tökéletesebb hely arra, hogy fejlesszük a repülőtéri biztonsági rendszereket, védelmi eszközöket, módszereket, eljárásokat, mint egy nemzetközi repülőtér. Abban az esetben jól múködik a szervezet, ha a motiváció, a tapasztalatok és azok feldolgozása, kapcsolatok, problémamegoldó és felismerő képesség jelen vannak. Ahhoz, hogy ezeket jól kihasználjuk, szükségünk van egy speciális vezetői hozzáállásra, aki a válságkezelést, a stratégiai gondolkodást, a professzionális problémamegoldást egyesíti. A menedzsment és az ehhez kapcsolódó módszerek rohamosan fejlődtek az elmúlt évtizedekben, és nem tudjuk eléggé hangsúlyozni, milyen fontos az, hogy a repülótéri-irányítás lépést tartson a fejleményekkel. A folyamattervezés manapság nem áll meg az elókészületekkel és a rendszeres tevékenységek operatív fejlesztésével. Ahol a klasszikus múveletek befejeződnek, ott kezdődik a kockázattervezés és a válságkezelés (tervek az enyhítésre, megelőzésre, előkészületekre, reagálás a lehetséges válságokra, újrafeldolgozás). Kockázat-orientált gondolkodásmód nélkül nem lehet a repülőterek kockázatos múveleteit kezelni. A kockázatkezelésnek két fontos eleme van. Mindenekelőtt, hogy képesek legyünk mindent kihasználni, ami segíthet megvédeni a repülőtereket esetleges terrortámadások ellen, ha az emberi erőforrások fejlesztésébe bevonnánk a kiképző személyzetet a biztonsági terület munkájába. Ahhoz, hogy képesek legyünk megtenni a szükséges lépéseket a modernizálásban és javítsuk a folyamatokat, a repülőtéri-irányítás nem kerülheti el a kockázattudatos gondolkodást. Másodszorra, repülőtéri személyzet, magasan képzett szakemberek, biztonsági őrök, adminisztratív személyzet vagy akár a tisztító személyzet is jelenthet kockázatot. Egy bizonyos mértékig mindenkinek meg kell tanulnia, hogy gondolkodnak a terroristák. Nincs olyan alkalmazott technológia, amely a hagyományos szolgáltatás-orientált módon talán hatékonyan megvédené az utasokat és azok értékeit az esetleges terrortámadások ellen, hacsak nem kombináljuk össze kevesebb optimizmussal és több erőszakos gondolattal. Hol tudnának ők ártani? Hogyan tudnának ártani? A mai ,hightech" világban előfordulhat, hogy a terroristák „low-tech” megoldásokkal akarnának tömeges megfélemlítést okozni és pusztítani? Vajon ők ugyanúgy lépés tartanak a gyakorlattal is, mint az elmélettel? Nekünk meg kell tanulnunk, hogy fejlesszük a technológiánkat, amely megváltoztatja az ő technikájukat. A biztonsági menedzsment szervezetében, a szenzor technológiák gyors fejlődése és a számítógépes adatfeldolgozás feltesz néhány kérdést. Jelen cikk nem teszi lehetővé, hogy az összessel foglalkozzunk, de egy párat kiemelünk belőlük. A rendelkezésre álló technológiával, például a földi és légi oldal területei, mind menedzselhető. Valamennyi technológia képes ellenőrizni nyitott területeket és számítógép vezérelt elemzéseket tenni, amelyek azonnali figyelmeztetéseket képesek kibocsájtani. Ha összehasonlítjuk a lehetőségeket, ki mondja, hogy a terroristáknak pontban ott kell lenni például a robbantás helyszínén? Ki mondja, 
hogy nem lehet-e megtámadni repülőteret a parkolóból? A terrorista módszerek hozzájárulnak ahhoz, hogy a repülőterek részlegesen vagy teljesen megváltoztassák a belső logisztikájukat. Moduláris struktúrák irányítják az utasok mozgását, korlátozzák a jeleket, mutatják vagy elrejtik az egyes érzékelőket és felszereléseket, vagy szabad hozzáférést biztosítanak egyes területekhez a repülőtéren, és ezek a változtatások nehezítik meg, hogy logisztikailag nehezebb legyen kivitelezni egy esetleges közvetlen terrortámadást. Minél bonyolultabb egy berendezés, annál kiszolgáltatottabb lehet. Hogyan lehet nagyon érzékeny eszközöket bebiztosítani rosszakaratú hatások ellen? Hogyan lehet őket megtámadni, megvédeni esetleges többi támadás ellen? Mit lehet tenni, ha az elektronikai vagy a vízrendszert támadják meg a repülőtereken? Hogyan tartsuk titokban azokat az eszközöket, felszereléseket, amelyek esetleg hasznosak lehetnek egy terrortámadáshoz? Ha megvannak a válságkezelő terveink, hogyan tegyük úgy titkossá, hogy közben a munkatársak hozzáférhessenek? Hogyan építsünk fel úgy egy szervezetet, hogy a munkatársaink ne adjanak ki minősített információkat arra jogosulatlan személyeknek? Hogyan tudunk minden munkatársat, utast, bolti eladót és a többi reptéri személyzetet felkészíteni arra, hogy a terrortámadásoknak az esélye minimalizálva legyen?

Mindezen kérdéseket meg kell vitatni stratégiai, szervezeti és operatív szinteken, ha szeretnénk a reptereink biztonságát növelni. A technológia elengedhetetlen, de a megfelelő emberi hozzáértés, együttműködési készség nélkül, akármilyen magas szintű gépeket is használunk, nem érjük el vele célunkat. És a legfontosabb megőrizni a repülőtereink biztonságát, az ott dolgozókét, és azokat az utasokét, akik a repülőterek szolgáltatásait használják. [4][13]

\section{ÖSSZEFOGLALÁS}

Általánosságban elmondható, hogy a kereskedelmi légitársaságok repülőgépeit háztartási vegyszerekből és folyadékokból összekevert kis bombákkal robbantották fel, amelyeket kézi poggyászokban juttattak a repülőgépek közelébe. Ezek a házi készítésű bombák épp elegendő erővel bírnak ahhoz, hogy nagy magasságokban szétszakítsanak egy repülőgépet. 1933 és 2010 között 92 olyan eset történt, ahol repülőgépet kíséreltek meg felrobbantani és 56 esetben halálozással járt. Statisztikák alapján elmondható, hogy az 1970es és 80-as évek között történt a legtöbb robbantás repülőgép fedélzetén, 1964 és 1989 között minden évben történt támadás kivétel 1977-et. 1985-ben öt támadás okozta 332 ember halálát, ahol az Air India járatán "csak” 182-en haltak meg. AZ 1990-es évektől kezdve egyre kevesebb alkalommal támadják meg a légitársaságok gépeit, de a terrorizmus további nagy fenyegetettséget jelent a kereskedelmi repülésre úgy, ahogy a 2001. szeptember 11-ei események is bizonyítják. A terroristák újabb és újabb módszereket, taktikát és eszközöket fejlesztenek, hogyan támadjanak meg egy repülőteret. Minden terrortámadás után bebizonyosodik, milyen fontos is repülötereink, dolgozóink, utasaink védelme. Szükségünk van tanfolyamokra, ahol folyamatosan fejlesztjük a humán erőforrásainkat, és javítjuk repülőtéri biztonságtechnikai felszereléseinket. A szenzor technológiának egyre nagyobb szerepe van a biztonságban, a biztonsági technológiákban, mint például repülőtéri biztonsági rendszerek, folyadék felderítés, szilárd robbanóanyagok detektálása, sugárzás, és így tovább. Megmutattuk, milyen különböző fajta repülőtéri detektáló berendezések vannak, és 
azok hogyan gyújtik össze a szükséges információt. Ahhoz, hogy elkerüljük a légiközlekedési baleseteket és a tömeges katasztrófákat, folyamatosan lépést kell tartanunk a terrorista szervezetek új eszközeivel és technikájával, amelyeket egyre nehezebb felismerni. De soha nem szabad megfeledkezni, hogy az emberi erőforrások folyamatos fejlesztése nélkül eszközeink nem nyújtanak teljes védelmet. [6]

\section{IRODALOMJEGYZÉK}

[1.] Szabó Vivien, Szegedi Péter: How does terrorism influence the airport security systems? http://www.afahc.ro/afastud/volum_afastud_2015.pdf, pp. 63-68.

[2.] Szegedi Péter, Szabó Vivien: Hogyan befolyásolja a terrorizmus a repülőterek biztonságát a technika szemszögéből? Múszaki Tudomány az Észak-kelet Magyarországi Régióban (2015.) Debrecen, 2015.06.11. pp. 194-206. (ISBN:978-963-7064-32-6)

[3.] Békési Bertold, Szegedi Péter, Szabó Vivien, Tóth József: How Terrorism Can Affect Technologycal Aspects of the Airport Security. Proceedings of 19th International Scientific Conference Transport Means (2015.) Kaunas, Technologija, 2015.10.22-23., pp. 112-115. (ISSN: 1822-296X)

[4.] Szegedi Péter, Békési Bertold, Koronváry Péter: Terrorism and Airport Security Some Technological Possibilities to Reduce Exposure. Deterioration, Dependability, Diagnostics. 2015.10.06-07. Brno, University of Defence pp. 279-288. (ISBN: 978-80-7231-431-7)

[5.] Szegedi Péter, Békési Bertold: Unmanned aerial vehicles based sensors, Proceedings of 19th International Scientific Conference Transport Means (2015.) Kaunas

[6.] http://www.aerospaceweb.org/question/planes/q0283.shtml [2015.10.28]

[7.] Szabó Vivien: A repülőtereken alkalmazott utasbiztonsági ellenőrzésen használt berendezések bemutatása, Tudományos Diákköri Konferencia, 2014

[8.] http://snallabolaget.com/?page_id=666 Letöltés: [2015.11.01.]

[9.] Sameer Singh and Maneesha Singh: Explosives Systems (EDS) for Aviation Security: A Review, PANN Research, Department of Computer Science, University of Exeter, Exeter EX4 4PT, UK

[10.] Charles M. Wynn, Stephen Palmacci, Roderick R. Kunz, and Mordechai Rothschild: A Novel method for Remotely Detecting Trace Explosives

[11.] Mercury Computer Systems: Automated Threat Detection for Baggage Screening

[12.] Richard Gesick, Caner Saritac, Chih-Cheng Hung: Automatic Image Analysis process for the Detection of Concealed Weapons

[13.] Douglas H. Harris: How to Really Improve Airport Security

[14.] Adrian Schawaninger, Diana Hardmeier, Franziska Hofer: Measuring Visual Abilities and Visual Knowledge of Aviation Security Screeners

[15.] Dana A. Shea, Daniel Morgan: Detection of Explosives on Airline, Passengers: Recommendation of 9/11, Commission and Related Issues

[16.] Richard W. Bloom: Airport Security, Which Poses the Greater Threat Passengers or Air Cargo? 
[17.] Veronique Rebuffel, Jean Rinkel, Joachim Tabary, Loick Verger: New Perspectives of X-ray Techniques for Explosive Detection Based on CdTe/CdZnTe Spectrometric Detectors

[18.] Szegedi Péter, Békési Bertold: Az UAV-on alkalmazható szenzorok, XIV. Természet-, Múszaki és Gazdaságtudományok Alkalmazása Nemzetközi Konferencia: Előadások: 14th International Conference on Applications of Natural, Technological and Economic Sciences: Proceedings from Conference. Konferencia helye, ideje: Szombathely, Magyarország, (2015.05.16) Szombathely: Nyugat-magyarországi Egyetem, Természettudományi és Múszaki Kar, Természetföldrajzi Tanszék, (2015.) (megjelenés alatt)

[19.] G. S. Hegde: Mechatronics, New Jersey: Princeton University Press, 2010, ISBN: 978-0691-14921-9;

[20.] Clarence W. de Silva: Mechatronics An Integrated Approach, Boca Raton London New York: CRC Press, 2005, ISBN: 0-8493-1274-4; 